\title{
Generating Electricity through Waste Burners: An Alternative Solution for Reducing Waste
}

\section{Ratih Anggraeni ${ }^{1}$, Ramadani ${ }^{2}$, Muhammad Najib Mauludi ${ }^{2}$, Affan Al-Maududi ${ }^{1}$, Muhammad Rifqi Saifullah ${ }^{1}$, and Muhammad Al-|rsyad ${ }^{1}$}

${ }^{1}$ Department of Public Health, Faculty of Sport Science, Universitas Negeri Malang, Malang, Indonesia

${ }^{2}$ Department of Mechanical Engineering, Faculty of Engineering, Universitas Negeri Malang, Malang, Indonesia

ORCID:

Ratih Anggraeni: https://orcid.org/0000-0003-3252-9809

Muhammad Al-Irsyad: https://orcid.org/0000-0003-1174-4075

\section{Abstract}

Waste is a wordlwide problem including in Indonesia. The increasing amount of waste is caused by the increasing human population. Proper waste management must be applied to avoid detrimental health and environmental consequences. One

Corresponding Author:

Ratih Anggraeni

ratih.anggraeni.1906126@

students.um.ac.id

Published: 25 March 2021

Publishing services provided by Knowledge E

(c) Ratih Anggraeni et al. This article is distributed under the terms of the Creative Commons Attribution License, which permits unrestricted use and redistribution provided that the original author and source are credited.

Selection and Peer-review under the responsibility of the ISMoPHS 2020 Conference Committee. way to manage waste is to design a device that could convert waste into electrical energy. This research aimed to provide a solution so that the volume of waste in Indonesia can be reduced and used as renewable energy. The methods used in this research were (1) identifying previous research on waste incineration and (2) designing a waste incinerator as appropriate technology and equipped with a system of utilizing the generated heat into electrical energy. The result of this research is the design of a device that can produce electricity from smoke and thereby reduce air pollution. Smoke from waste burning in a furnace was first filtered using a carbon cloth material to reduce air pollution. The heat from combustion was used to boil the water and change it into fumes above $100^{\circ} \mathrm{C}$. The steam produced had potential energy which was converted into kinetic energy through a turbine that can move the shaft to produce mechanical energy. Mechanical energy was then used to rotate the generator shaft that generated electric current and was then used to charge the battery. The battery power was then distributed for regualr use using a power converter.

Keywords: combustion, design, electricity, environment, health, waste

\section{Introduction}

Garbage is a problem in almost all countries in the world, including Indonesia. Currently, Indonesia is the third-largest contributor to waste in the world. Indonesia produces 64 million tonnes of waste every year, with the composition of waste being dominated by organic waste by $60 \%$, plastic waste $14 \%$, paper waste $9 \%$, and rubber waste $5.5 \%$ of the 
total waste [1]. In 2019, waste production in Indonesia increased to 68 million tons, with a composition of $70 \%$ organic waste, $14 \%$ plastic waste [1]. The population of Indonesia is 269.6 million [2]. Waste production in all regions in Indonesia has also increased significantly. East Java Province with 38 city districts produces an average of 18,500 tons/day of waste and it is estimated that only half of it is handled [3]. The amount of waste dumped in Malang is $\mathbf{4 7 3 . 2 2}$ tons/day and unmanaged waste is 186.66 tons/day [4]. Waste production in Malang City is dominated by domestic waste such as in offices, Islamic boarding schools, and waste generated by the daily activities of the community.

The very high waste production results in the capacity exceeding the capacity of the waste processing facility. The increase in the volume of waste every day is due to unbalanced waste production and processing [5]. The need for land for waste landfills (TPA) is one of the problems due to the failure to process waste effectively and efficiently. The need for landfill land is rapidly increasing due to not carrying out an effective waste volume reduction process [6]. 69\% of total waste in Indonesia ends up in landfills from a total of 65 million tonnes every day [7]. The processing of waste in Indonesian cities is still carried out conventionally, namely the open dumping method and sanitary landfill.

The conventional waste processing process creates various environmental and health problems. The potential that occurs is a pungent odor to the spread of disease around the landfill. Diseases caused by waste include hepatitis, cholera, dysentery, skin diseases, typhoid, and water quality pollution. Conventional waste processing techniques by burning or open burning harm the atmosphere in the form of pollution of greenhouse gases and toxic gases such as $\mathrm{CO}, \mathrm{SO}_{2}$, and $\mathrm{NO}_{2}$. So far, waste processing technology has not been optimal so that waste is not handled properly. The waste management paradigm must be based on the concept of waste processing that supports the principles of sustainable and environmentally sound development [8]. Waste management with the principle of sustainable development can be implemented by converting waste into energy or waste to energy (WTE) [8].

Proper waste management must be carried out immediately because if the amount of waste is increasing and it is not managed properly, it will have consequences for health and the environment. To reduce the amount of waste, it is necessary to design a device that can convert waste into electrical energy and not harm health and the environment. This research is shown to provide a solution so that the volume of waste in Indonesia can be reduced and used as renewable energy in the form of electricity. 


\section{Material and Method}

An alternative electricity-producing garbage burner is a device designed to burn waste and smoke is filtered using a smoke filter and the heat from burning waste is used to heat water in a boiler which is designed in such a way that it will produce steam and extracted into electrical energy. The method used in this research is as follows.

\subsection{Identification of tool components}

Develop component specifications that have functions following tool requirements. All information about the specification must be met by the component and can identify constraints that could reduce the effectiveness of the tool. This stage adjusts the needs of the community by taking into account market conditions and the country's economy to produce good results.

\subsection{Concept design of tools}

This product concept is a solution to a design problem that must be solved. The product concept is a simple schematic image that describes the product as a whole. Alternative product concepts are evaluated for further development. Evaluation is carried out by several specific criteria such as technical criteria, economic criteria, and others. Product concepts that do not meet the requirements in the product specifications are not processed to the next stage, while product concepts that meet the criteria are selected as the best solution to be developed.

\subsection{Design tool}

At this stage, the concept design of the tool is given a form that initially is only a scheme to become a form in such away. These components compose the form of the product according to the scheme so there is no collision and can run according to its function.

\subsection{Detail design}

In the detailed design stage, then the arrangement of product components, shape, dimensions, surface smoothness, the material of each product component is determined. Likewise, the possibility of how to manufacture the product has been done and 
the estimated cost has been calculated. The final result of this stage is a complete design drawing and product specifications for manufacture.

\section{Results}

\subsection{Main design of tool}

Components The main components of the tool being designed are in the form of a combustion furnace, steel frame, smoke filter, boiler, turbine, and generator.

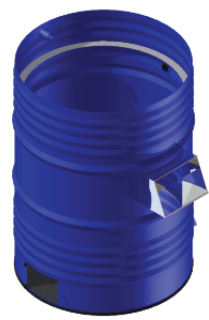

(a)

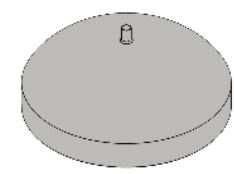

(d)

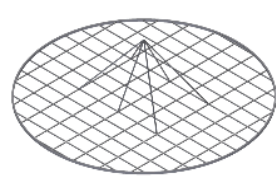

(b)

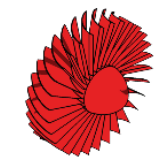

(e)

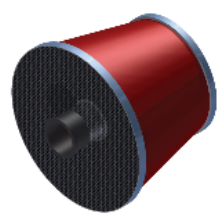

(c)

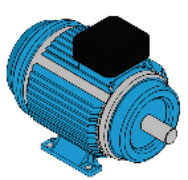

(f)

Figure 1: Components of tool design (a) Furnace, (b) Steel frame, (c) Smoke filter, (d) Boiler, (e) Steam Turbine, and (f) Generator. (Source: Author's own work.)

Combustion furnace (a) functions as a trash incinerator and place of the energy conversion cycle from heat to steam. The iron frame (b) functions as a separator between combustion chamber waste and combustion waste chambers such as ash or charcoal. The smoke filter $(C)$ functions as a filter for smoke from combustion in the furnace such as $\mathrm{CO}, \mathrm{SO}_{2}, \mathrm{NO}_{2}$, etc. Boiler (d) functions as a container for heating water with heat that comes from burning waste. Steam turbine (e) Serves as a converter of potential steam energy into kinetic energy and then converted into mechanical energy that will drive electricity-producing generators. Generator (f) functions as a converter of mechanical energy into electrical energy.

\subsection{Concept design}




\subsubsection{Identification of Needs}

Identification is used as a requirement before the implementation of product manufacturing is carried out. The required waste processing technology requirements are shown in Table 1 below.

TABLE 1: Identification of needs.

\begin{tabular}{l|l|l} 
No. & Fulfillment & Level of importance \\
\hline 1 & Able to Process Waste with Aerobic Process & very important \\
2 & Easy Installation and Installation & very important \\
3 & Easy Maintenance and Repair & important \\
4 & Easy to move & important \\
5 & Weather and Disaster Resistant & very important
\end{tabular}

\subsubsection{Designing the product concept}

After carrying out the identification process, the function blocks used in the waste processing system are determined. The following is the concept of an alternative electricity generating waste burner.

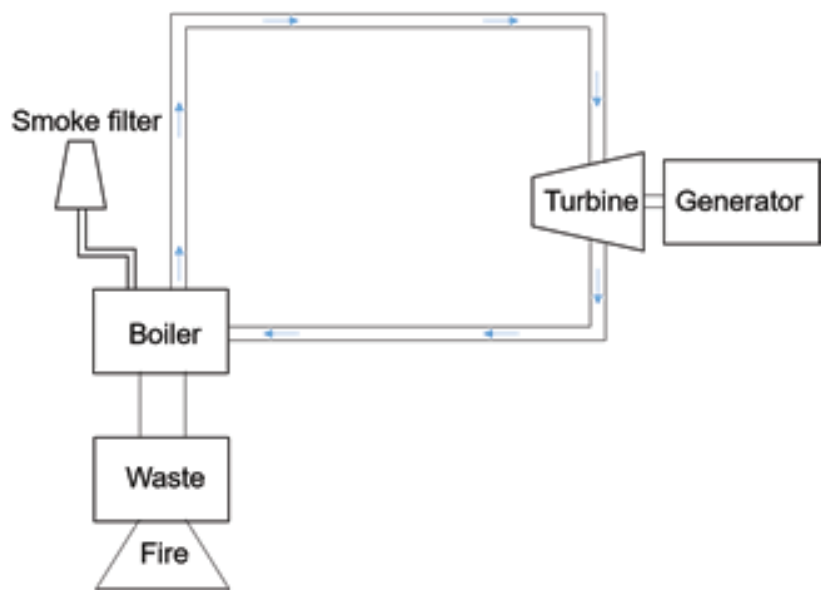

Figure 2: The Concept of an alternative electricity generating waste burner. Source: Author's own work.

\subsection{Designing tool: The shape}

Design of an electricity-producing waste burner consists of several components that are designed and then assembled according to the tool concept scheme. The following is a form of design that has been made. 


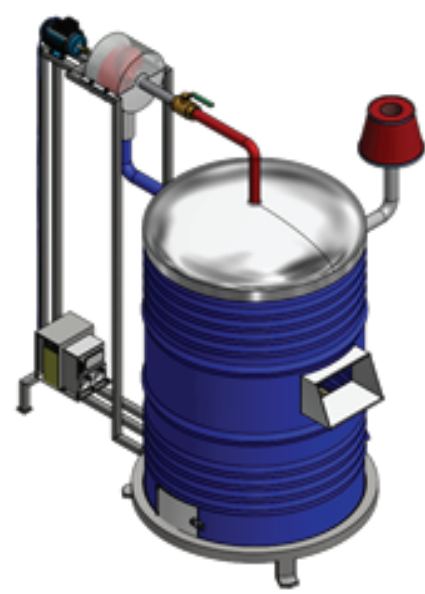

Figure 3: Design of an electricity-generating waste burner. Source: Author's own work.

\subsection{Design of a detailed tool}
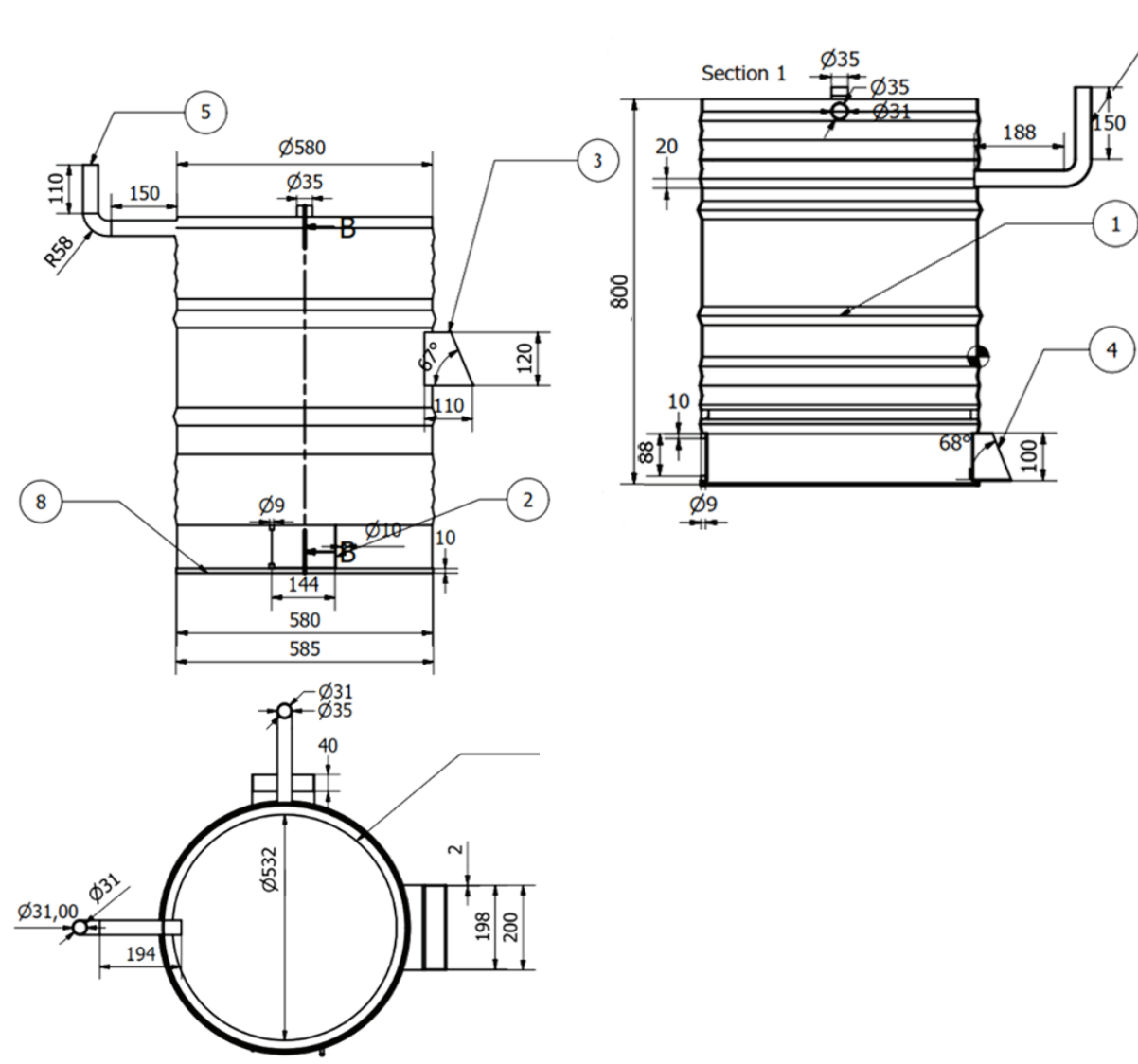

Figure 4: The design of the furnace for the electric-generating waste burner. Source: Author's own work. 
TABLE 2: Part list of combustion stove.

\begin{tabular}{|l|l|c|}
\hline Items & Part number & Material \\
\hline 1 & Combustion stove & Steel plate \\
\hline 2 & Source fire & Iron plate \\
\hline 3 & Trash in & Iron plate \\
\hline 4 & Disposal of ash & Iron plate \\
\hline 5 & Steam pipe & Iron \\
\hline 6 & Smoke pipe & Iron \\
\hline 7 & Buckle of iron frame & Iron \\
\hline 8 & Buckle of boiler & Iron \\
\hline
\end{tabular}



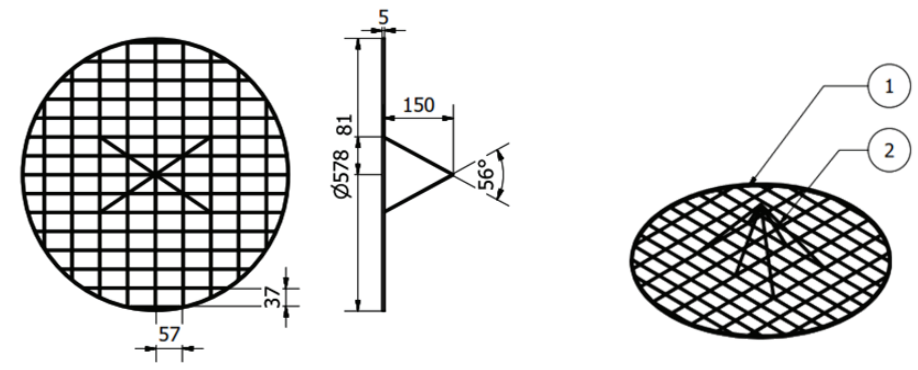

Figure 5: The design of the iron frame for the electric-generating waste burner. Source: Author's own work.

TABLE 3: Part list of iron frame.

Items
1
2

Part number
Iron frame
Round bars

Material

Steel

Steel
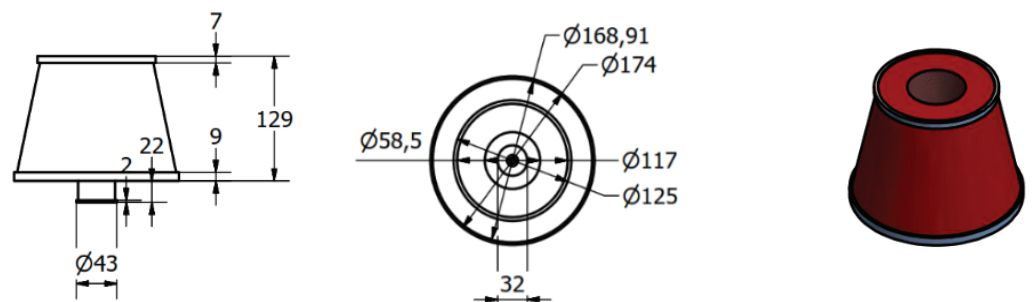

Figure 6: Design of smoke filter for electric-generating waste burners. Source: Author's own work.

TABLE 4: Part list of smoke filter.

\begin{tabular}{|l|l|c|}
\hline Items & Part number & Material \\
\hline 1 & Smoke filter & Iron plate \\
\hline 2 & Carbon & Carbon fabric \\
\hline
\end{tabular}

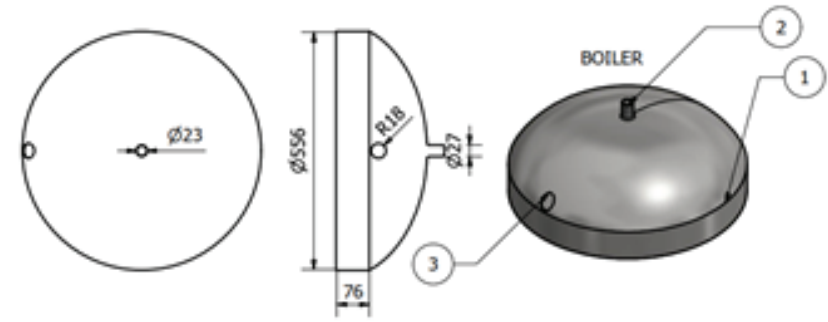

Figure 7: Biler design. Source: Author's own work.

TABLE 5: Part list of boiler.

Items
1
2
3

Part number
Boiler
Steam hole
Hole in dew

Material

Stainless steel

Stainless steel

Stainless steel 


\section{Discussion}

\subsection{Main components}

The furnace is designed by the availability of easily available materials, namely used drums. The dimensions of the furnace areas in Figure 4 and show the furnace material is made of steel plate [9]. In this component, there are several parts, namely the door of the fire source, the entrance to the garbage, the door to dispose of the ashes from the combustion, the smoke pipe, the steam pipe, the iron frame support, and the boiler support. All parts of the combustion furnace are described in Figure 4. This furnace can accommodate $15-20 \mathrm{~kg}$ of waste so that in this component the combustion process can be done in a cycle. If the waste in the furnace burns out, the remainder of the combustion in the form of ash can be removed through the ash exit.

The smoke from combustion is filtered using a smoke filter. The smoke filter is shown in Figure 6 by the dimensions of the smoke inlet adjusted by the size of the smoke outlet. The used material is metal, and the composition of the filtering material in the filter consists of first filtering with a foam that is quite tenuous in density, followed by a pre-filter then the smoke is passed to the pre-carbon filter and finally the smoke is filtered using a high-density carbon cloth and has the function of eliminating odors [10].

The process of converting heat energy into steam occurs in boiler components. The boiler design is shown in Figure 7 by dimensions adjusted by the diameter of the furnace and the size of the turbine to be rotated. The material used is stainless steel because it has a high level of strength and is a good heat conductor. The process of making this boiler is carried out using TIG welding. It has a better density because it uses argon gas as a protector [11]. The energy conversion process initially occurs in the boiler section, the fire stage generated by burning waste used to heat the water in the boiler. Water will change phase to steam at temperatures above $100^{\circ} \mathrm{C}[12]$.

The steam produced by the boiler has potential energy [13] so that in the design of this tool, steam will be channeled to the steam turbine through pipes and valves. The potential energy of the steam then is converted through the turbine into kinetic energy that can move the shaft to produce mechanical energy. Mechanical energy is used to rotate the generator shaft. The rotating generator will induce electromagnetics so that it will generate an electric current [14]. 


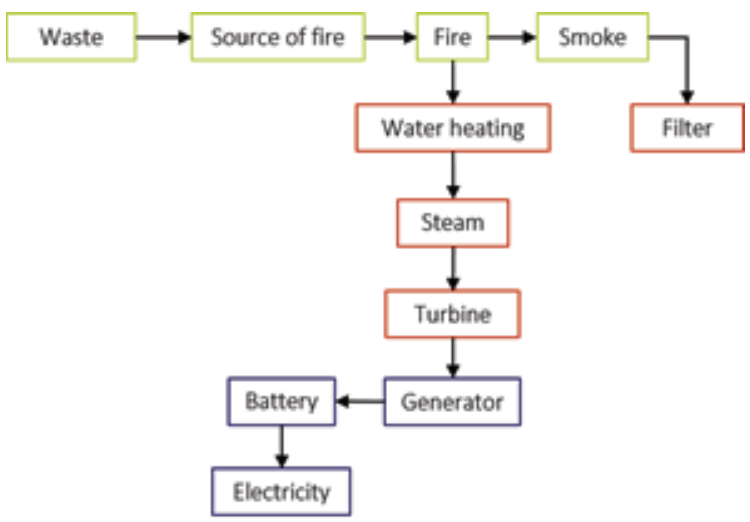

Figure 8: Workflow for electric-generating waste burners. Source: Author's own work.

\subsection{Workflow for tools}

Figure 8 shows the workflow for electric-generating waste burners. The workflow of this tool begins with the waste being put into a furnace and burned then the results of combustion are in the form of fire and smoke. The smoke from combustion is in the filter so as not to cause air pollution. Fire is used to heat the water in the boiler. So that boiling water will produce water vapor which has potential energy in the form of pressure. The flowing stream fluid is channeled through the pipe and the valve and passed to the turbine which causes the turbine to rotate. The rotation of the turbine has kinetic energy which becomes mechanical motion which is used to drive an electric generator. The electricity generated from the generator is stored in the battery. Then the electric power from the battery is then converted to the electrical control section and the electricity generated can be used for various purposes.

\subsection{Specifications and advantages of tool design}

The electric-generating waste burners have a combustion furnace with a volume capacity of $15-20 \mathrm{~kg}$. The steam pressure generated from burning waste is 1.2 bar with a steam speed of $34.95 \mathrm{~m} / \mathrm{s}$. The turbine rotation speed which is affected by the combustion smoke is $120 \mathrm{rpm}$ max and the generator capacity of the combustion engine is 300 watts. The battery used in the burner is 24 volts with a converter of 350 watts. The electric power generated is 300 watts and an efficiency of $80 \%$.

The advantages of this tool design provide many benefits for health and the environment. This tool can reduce the waste population that is generated every day so that it can reduce health and environmental problems caused by the garbage that is around. This tool is also able to reduce air pollution resulting from burning waste in the 
equipment used from filtering the engine. So, this tool can create a healthy environment and avoid diseases caused by garbage and air pollution resulting from combustion.

\section{Conclusion}

The conclusion of this study is the creation of a design tool that can produce electrical energy and smoke from combustion does not pollute the environment by burning the waste in the furnace then the smoke is filtered using a smoke filter modified with the material. additional in the form of a carbon cloth so that the smoke from the combustion is cleaner. The heat from combustion is used to boil the water and change it into fumes above $100{ }^{\circ} \mathrm{C}$. The steam produced has potential energy and is converted through a turbine into kinetic energy that can move the shaft to produce mechanical energy. Mechanical energy is used to rotate the generator shaft that will generate electric current and then used to charge the battery. Distribution of battery power for usual use using a power converter. This design concept can reduce the presence of waste in Indonesia effectively and efficiently so that it does not cause bad impacts on the environment and health.

\section{Acknowledgement}

This research supported by Kementerian Pendidikan dan Kebudayaan Republik Indonesia 2020

\section{Conflict of Interest}

The authors state that there is no conflict of interest.

\section{References}

[1] Widowati, E. (2019, November). Komposisi Sampah di Indonesia Didominasi Sampah Organik. Retrieved from https://databoks.katadata.co.id.

[2] BPS. (2019). Statistik Indonesia 2019. Jakarta: Badan Pusat Statistik.

[3] Hidup, D. L. (2019). Penanganan dan Pengendalian Sampah Regional di Jawa Timur. Retrieved from https://dlh.jatimprov.go.id

[4] Bank Sampah Malang. (2018). Emas Hitam Dibalik Tumpukan Sampah. Malang: BSM. 
[5] Rhohman, F. and Ilham, M. M. (2019). Analisa dan evaluasi rancang bangun insinerator sederhana dalam mengelola sampah rumah tangga. Jurnal Mesin Nusantara, issue 2, pp. 52-60.

[6] Permana, A. G. and Iqbal, M. (2019). Mesin Pengolahan Sampah Portabel Multiguna Dengan Teknik Termocontrol Dan Termocople. SEBATIK 1410-3737, vol. 23, issue 2, pp. 423-30.

[7] Muiz, A., et al. (2017). Perancangan Pembangkit Listrik Tenaga Sampah Organik Zero Waste di Kabupaten Tegal (Studi Kasus di TPA Penujah Kanupaten Tegal). Jurnal Teknik Mesin, Vol. 6, issue 4, pp. 282-289.

[8] Susastrio, H., et al. (2020). Kajian Incinerator Sebagai Salah Satu Metode Gasifikasi Dalam Upaya Untuk Mengurangi Limbah Sampah Perkotaan. Jurnal Energi Baru dan Terbarukan, vol. 1, issue 1, pp. 26-31, https://doi.org/10.14710/jebt.2020.8135.

[9] Pribadi, A. (2018). Krakatau Steel Bakal Pasok Material Drum Sheet Aspal Pertamina. Retrieved from https://www.wartaekonomi.co.id/read169465/krakatau-steel-bakalpasok-material-drum-sheet-aspal-pertamina.

[10] Sasongko, D. (2016, Februari 27). Lima mahasiswa Universitas Brawijaya Malang menemukan sebuah alat yang berfungsi sebagai penyaring udara kotor. Alat itu diberi nama Automatic Sedot Asap Polusi (ASAP). Retrieved from https://m.merdeka.com/peristiwa/mahasiswa-universitas-brawijaya-temukanalat-penyaring-udara-kotor.html.

[11] Suastiyanti, D. and Hasybi, M. K. (2018). Kekerasan Hasil Pengelasan TIG dan SMAW pada Stainless Steel SS 304 untuk Aplikasi Boiler Shell. Prosiding Seminar Nasional Pakar Tahun 2018 Buku I, pp. 47-52.

[12] Susana, T. (2003). Air Sebagai Sumber Kehidupan. Oseana, vol. 28, issue 3, pp. $17-25$.

[13] Purba, J. (2016). Perancangan Boiler Pipa Api Untuk Perebusan Bubur Kedelai pada Industri Tahu Kapastas Uap Jenuh 160 kg/jam. Jurnal Mahasiswa Teknik UPP, Vol. 2, issue 1, pp. 1-8.

[14] Muchta, A. (2018). Prinsip Kerja Generator Listrik (AC dan DC) + Rangkaian. Retrieved from https://www.autoexpose.org/2018/02/prinsip-kerja-generator-listrik.html?m=1. 